UDC 629.3.014.7+629.3.022.4

L. Petrov, PhD, Assoc. Prof.,

Y. Petryk

Military Academy (Odessa), 10 Fontanska doroga Str., Odessa, Ukraine, 65009; e-mail: leonid.petrov2@gmail.com

\title{
THEORETICAL RESEARCHES OF A CAR WHEEL WITH A TRACTION COMPENSATOR
}

\begin{abstract}
Л.М. Петров, Ю.М. Петрик. Теоретичні дослідження автомобільного колеса з компенсатором тягового зусилля. Робочий процес кочення колісного рушія супроводжується навантаженням колісного рушія силою гравітаційного навантаження, що приводить до стискання та розтягування шини при ії деформації. В статті розглянуті питання дослідження механічної системи «автомобільне колесо-пружинний компенсатор тягового зусилля», з застосуванням теореми про зміну кінетичної енергії цієї системи, загального рівняння динаміки, а також рівняння Лагранжа другого роду. Метою дослідження є удосконалення конструкторсько-технологічної схеми кочення колісного рушія, перетворення енергії підведеної до колісного рушія в обертальний рух колісно-пружного компенсатора тягового зусилля , який $є$ допоміжним фактором до цієї технології. Наукова та практична значущості роботи полягає в тому, що вперше запропонована технологія в якій при обертанні колісного рушія введено частка енергії обертального руху механічної системи «автомобільне колесо-пружинний компенсатор тягового зусилля», яка дозволяє значно підвищити тягове зусилля колісного рушія. Методологією дослідження являлося встановити математичний зв'язок силою, яку створює «автомобільний колісно-пружинний компенсатор тягового зусилля», з додатковим шляхом, який проходить колесо. Результатом $є$ розроблена геометрія роботи колісного рушія у циклі демпфування «автомобільним колісно-пружинним компенсатором тягового зусилля» провалу опорної поверхні. Цінність проведеного дослідження, результати проведеної роботи дозволять зробити внесок в галузь автомобільного виробництва. Запропоновано модель для підвищення тягових можливостей транспортного засобу.

Ключові слова: фізико-математична модель, рушій, колесо, колісно-пружний компенсатор

L. Petrov, Y. Petryk. Theoretical researches of a car wheel with a traction compensator. The rolling process of the wheel drive is accompanied by the loading of the wheel drive by the force of gravity, which leads to compression and stretching of the tire during its deformation. The article deals with the study of the mechanical system "automobile wheel-spring compensator of traction force", using the theorem on the change of kinetic energy of this system, the general equation of dynamics, as well as the Lagrange equation of the second kind. The purpose of the study is to improve the design and technological scheme of rolling the wheel drive, converting the energy of the wheel drive into the rotational motion of the wheel-elastic traction compensator, which is an auxiliary factor to this technology. The scientific and practical significance of the work lies in the fact that for the first time a technology was proposed in which the share of rotational motion energy of a mechanical system "automobile wheel-spring traction compensator" was introduced during rotation of a wheel drive, which significantly increases traction. The research methodology was to establish a mathematical relationship between the force created by the "car wheel-spring traction compensator" and the additional path that the wheel travels. The result is the developed geometry of the wheel drive in the damping cycle "automotive wheel-spring traction compensator" failure of the bearing surface. The value of the study, the results of this work will contribute to the automotive industry. A model for increasing the traction capabilities of the vehicle is proposed.

Keywords: physical-mathematical model, engine, wheel, wheel-elastic compensator
\end{abstract}

\section{Introduction}

Transport and transport-technological machine (car) is characterized by its purpose, ie the ability to meet human needs in a particular field of activity. Therefore, the car must have many useful qualities as well as resource-saving and environmental properties that directly affect the quality of the car. Operating properties are the properties that determine the degree of suitability of the car for operation as a specific (ground wheeled, non-rail) vehicle. There are the following main group properties that ensure the movement of the car. These are traction-speed and braking properties; fuel efficiency; controllability; stability; maneuverability; smoothness and passability. The impact of group properties on the quality of the car as a whole depends on the operating conditions, which are determined by road (terrain, type and levelness of road surface, intensity and modes of traffic, road profile and plan characteristics), transport (type and volume of traffic, distance, type of route, etc.), and climatic (features of operation in temperate, cold, hot and alpine climates) conditions.

Problems of improving the performance of the car are one of the main in the automotive industry. Their decision is being made in different directions. Namely: increase in productivity; increase of technical

\section{DOI: 10.15276/opu.1.63.2021.03}

(C) 2021 The Authors. This is an open access article under the CC BY license (http://creativecommons.org/licenses/by/4.0/). 
and economic and improvement of ecological indicators and reliability; use of new types of fuel and types of engines; reduction of energy losses in various units (rolling resistance, aerodynamic resistance, transmission losses, etc.); improvement and automation of machine control systems and a number of other areas of both theoretical and experimental researches. Each design improvement should be based on the methods of mathematical modeling (calculation) and a comprehensive analysis of the performance of the car.

New powerful trucks play an important role in improving the capacity of large volumes of cargo. New trucks should have higher energy saturation and run at higher speeds. This requires the development of constructive developments of new technological solutions, as well as the justification of the main parameters associated with the rolling of the wheel drive of cars [1]. During the interaction of the chassis of the truck with the ground, it is deformed. The deformation remains in the form of a track, as well as in the instantaneous deformation of the tire. The ability to move, carry out transportation and technological operations in the conditions of weakly bearing bearing surfaces has a great influence on the development of the economy and infrastructure in these regions where the car is operated. Only a vehicle with low engine pressure on the ground can move on the support base with low bearing capacity. The efficiency of operation of trucks in difficult road conditions is largely determined by their passability. The problem of passability of trucks on bearing surfaces with low bearing capacity is solved mainly by improving the design of the engines. In the general case, the world's leading truck manufacturers make the following requirements for propulsion [2]:

- maximum efficiency (increase of passability and traffic safety);

- versatility (possibility of use in a wide range of operating conditions);

- high traction and coupling qualities;

- minimal movement losses;

- rational interaction with the base surface in terms of preserving its ecology;

- quality indicators of controllability and stability;

- good elastic and cushioning properties;

- good self-cleaning;

- high strength and reliability, sufficient wear resistance and durability;

- ease of operation (simplicity and speed of installation, dismantling and repair of engines);

- light weight and low cost.

These requirements are met by pneumatic tires, which complement the wheel drive of the truck $[3,4]$. Pneumatic tires are one of the simplest and most effective means of increasing the passability of wheeled vehicles. By varying the basic parameters of the tires (size, shape, number of layers, cord, material, internal pressure, pattern and tread depth), you can change the coefficients of adhesion and rolling resistance, as well as the plane of contact between the wheel and the bearing surface and, accordingly, pressure on her. The use of wheeled engines allows trucks to provide high speeds and high economic performance. The development of pneumatic wheels in the direction of increasing passability was the creation of highly elastic ultra-low pressure tires on the basis of existing wide-profile tires. Such ultra-low pressure tires have a thin-walled rubber-cord sheath with a frame, which structurally consists, as a rule, of two layers of cord, due to which its high elasticity is ensured. When rolling a wheel with such a tire, the stress in the area of contact of this tire with the support surface is distributed very evenly, both along the length and width of the contact with the support surface, reducing the ultimate loads on the soil protrusions and preventing its destruction. When interacting with the ground, such a tire does not destroy its surface and acquires the ability (to flow around) the unevenness of the road. The protrusions and depressions of the tread repeat the profile of the road surface and act as ground hooks, increasing the adhesion to the bearing surface.

\section{Analysis of literature data and problem statement}

2.1. Review of previous studies

The movement of the car occurs under the action of the forces applied to it. The forces acting on the car can be divided into three main groups: 
- Weight force;

- The force of resistance to movement;

- The force of movement of the car.

The car can also act on various inertial forces, the nature of which is determined by the circumstances of the movement.

The component of the force of gravity of the car, depending on the circumstances of movement can be the driving force (movement of the car uphill), or the force of resistance (movement of the car uphill).

When a car wheel rolls, its tire and the road on which the wheel rolls are deformed, which depends on the properties of the tire and road material, road condition, forces and moments applied to the wheel, wheel size, tire pressure. Deformation of the tire and the road is accompanied by internal friction in the material of the tire and the road, as well as friction between them, as a result of which energy is expended when rolling the wheel.

Wheel rolling can occur under the action of a force applied to its axis (driven wheel) or under the action of torque applied to the wheel (driving wheel). The forces and moments acting on the wheel, cause reactions between the road and the wheel, the law of distribution of which on the bearing surface depends on many factors.

Wheel rolling can be considered in the following cases:

- Rolling of the deformable wheel on a hard surface;

- Rolling of the deformable wheel on soft soil;

- Rolling of a rigid wheel on a deformable surface;

Requirements for the wheel rolling process:

1. Only the pushing force is applied to the wheel axis (driven mode);

2. Torque is applied to the wheel axis.

2.2. Rolling wheel in the driven mode

Uniform wheel movement, Fig. 1.

Automobile wheel drive $[5,6,7]$ with radius $R$, which has a gravitational weight $G$, and which can rotate near the horizontal axis perpendicular to the plane of the drawing, and which passes through the point $O$. The wheel begins to rotate without the initial angular velocity, Fig. 1.

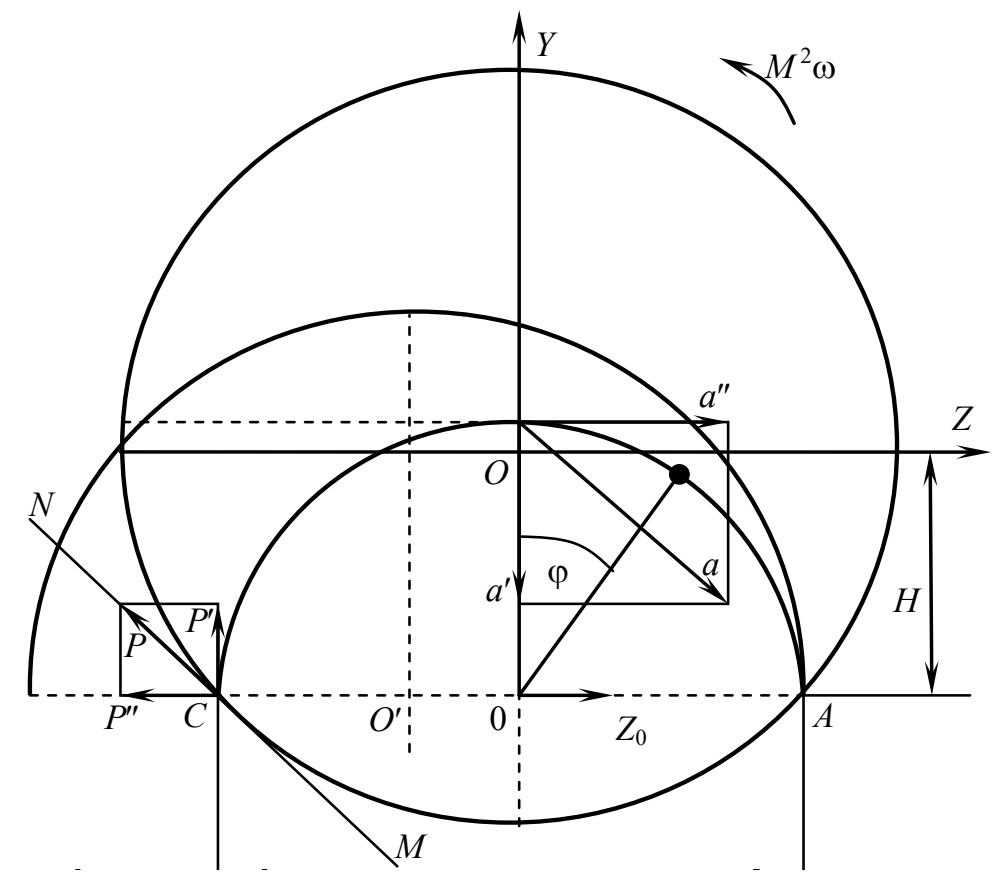

Fig. 1. Physical model of wheel rotation 
The angular velocity and angular acceleration of rolling of the wheel drive of the car are determined at the horizontal position of the contact spot - the segment $[A C]$. When the car wheel rotation rotates, the contact, ie the segment $[A C] / 2$, rotates near the $x$-axis perpendicular to the drawing plane (physical model of wheel rotation).

In this case, the trajectory of point $A$, which is outside the contact spot, will move described by the radius of the $[A C]$, and thus the movement of point $A$ will be directed to point $C$. The angular velocity of the car wheel is determined at a time when the segment $\left[O A_{1}\right]$ is with the vertical axis $\varphi$. For the proposed physical model of wheel drive rolling, the theorem on the change of kinetic energy of a mechanical system in the form of the equation is applied:

$$
T-T_{0}=\sum A_{i}^{E},
$$

where $T_{0}=0$, as the movement of the automobile wheeled engine began from a state of rest.

The speeds of the points of the wheel drive at the point of contact with the surface during spherical motion at any time can be considered as rotation near the instantaneous axis of rotation. Therefore, the kinetic energy of the contact trace, which is directly on the bus, performs a spherical motion and will currently be determined from the formula:

$$
T=\frac{1}{2} I_{z} \omega^{2},
$$

The inertial component of the moment of the contact trace relative to the $Z$ axis of its rotation in the direction of motion is found from the formula:

$$
I_{z}=I_{C z}+m \cdot R^{2}=\frac{m \cdot R}{2}+m \cdot R^{2}=\frac{3}{2} \cdot m \cdot R^{2},
$$

where $m$ - the weight acting on the trail of contact of the wheel drive with the support surface; $R$ rotation of the contact spot.

To obtain the results of the interaction of the car wheel drive with the support surface used previously obtained formulas (2) and (3). To do this, the authors substituted the values of the inertial component of the contact trace moment relative to the $Z$ axis of its rotation in the direction of motion Iz from formula (2) to formula (3). Then the equation was obtained:

$$
T=\frac{3}{4} \cdot m \cdot R^{2} \cdot \omega^{2}=\frac{3}{4} \cdot \frac{G}{g} \cdot R^{2} \cdot \omega^{2} .
$$

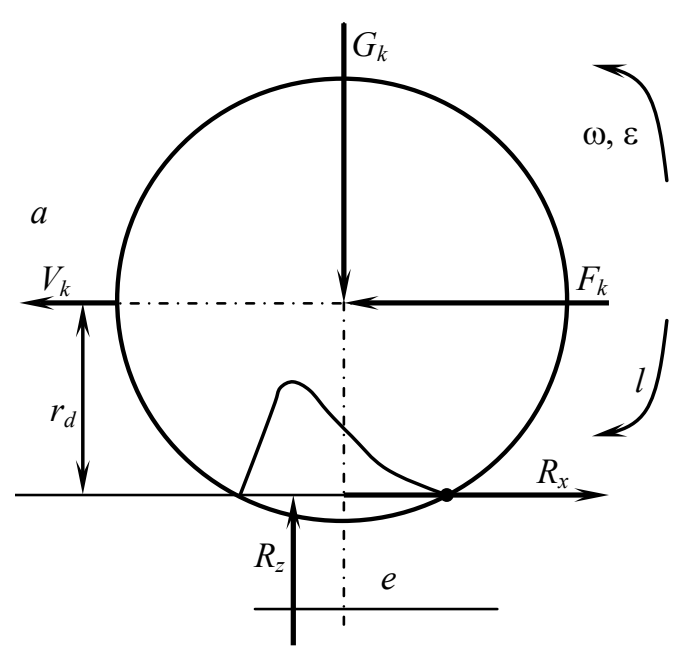

Fig. 2. Rolling the wheel on a soft surface

When rolling a car wheel drive, energy is expended to overcome the resistance forces of the road. The work spent on overcoming the forces of rolling resistance of the wheel drive from the force of gravity, is determined by the formula:

$$
A_{G}=G \cdot H=G \cdot R \cdot(1-\cos \varphi),
$$

where $G$ - truck weight force; $H$ - the distance from the support surface to the center of the wheel drive

Fig. 2 shows a physical model of wheel rolling on a soft surface.

The force acting on the wheel will be determined by the formula:

$$
F_{k}=G_{k} \frac{e}{r_{d}}+\frac{T_{u}}{r_{d}}=G_{k} f+\frac{T_{u}}{r_{d}},
$$

where $e / r_{d}=f$ - rolling resistance coefficient (coefficient of friction of the second kind). 
The coefficient $f$ depends on the design of the tire, the pressure in it, its performance properties and the path.

$$
f=f_{k}+f_{k g},
$$

where $f_{k}$ - rolling resistance coefficient of the deformable body on non-deformable soil; $f_{k g}-$ coefficient of rolling resistance on soft soil.

The speed of rolling is significantly influenced by the speed of the car. With increasing forces of inertia, the deformation of the tire increases, and, consequently, the cost of internal friction.

\section{The purpose and objectives of the study}

The purpose of the study is to improve the design and technological scheme of rolling the wheel drive, converting the energy supplied to the wheel drive in the rotational motion of the wheel-elastic traction compensator, which is an auxiliary factor to this technology, and improving the technology of energy transfer from the engine to wheels models of interaction of the loaded wheel drive with the deformed basic surface.

The results of the study, which are given in the monograph [8], were used as auxiliary material.

\section{Materials and methods of research}

4.1 Theoretical studies of the elastic traction compensator on a wheel drive

To study the mechanical system "automobile wheel-spring traction compensator", we apply the theorem on the change of kinetic energy of this system, the general equation of dynamics, as well as the Lagrange equation of the second kind.

In integral form, the theorem on the change of kinetic energy of a mechanical system "automotive wheel-spring traction compensator" will have the form:

$$
T_{1} T_{0}=\sum_{k} A_{k}^{e}+\sum_{k} A_{k}^{i},
$$

where $T_{1}, T_{0}$ - kinetic energy of the system "automobile wheel-spring compensator of traction force", according to the final and initial position; $\Sigma_{k} A_{k}^{e}+\Sigma_{k} A_{k}^{i}$ - work forces, respectively, external and internal forces of the system "car wheel-spring traction compensator", when moved from the initial position to the final.

For a fixed system:

$$
\sum_{k} A_{k}^{i}=0 .
$$

With the translational motion of the mechanical system "automotive wheel-spring traction compensator", the formula of kinetic energy takes the form:

$$
T=\frac{1}{2} M V \frac{2}{c},
$$

where $M$ - solid mass; $V_{c}$ - the speed of the center of mass.

When the rotational motion of the body around a fixed axis:

$$
T=\frac{1}{2} I_{z} \omega^{2},
$$

where $Y_{z}$ - the moment of inertia of the body around the axis of rotation; $\omega$ - angular velocity of the mechanical system "automobile wheel-spring compensator of traction force".

In the general case, with a plane of translational motion for the mechanical system "car wheelspring traction compensator":

$$
T=\frac{1}{2} M V \frac{2}{c}+\frac{1}{2} I \omega^{2},
$$

where $M$ - mass of mechanical system "automobile wheel-spring compensator of traction force"; $V_{c}$ - speed of the center of mass of the mechanical system "automobile wheel-spring compensator of 
traction force"; $Y_{c z}$ - moment of inertia of the mechanical system "automotive wheel-spring traction compensator", which does not pass through the center of mass $C$ perpendicular to the plane of motion; $\omega$ - angular velocity of the mechanical system "automobile wheel-spring compensator of traction force".

For the mechanical system "automobile wheel-spring traction compensator" with holonomic and holding elms, the general equation will look like:

$$
\sum_{k} \delta A_{k}^{a}+\sum_{k} \delta A_{k}^{i n}=0
$$

where $\sum_{k} \delta A_{k}^{a}$ and $\sum_{k} \delta A_{k}^{i n}$ - the amount of work, respectively, of the active forces and the forces of inertia on the possible displacements of the beginning of the application of these forces.

The study of the mechanical system "automobile wheel-spring traction compensator" was carried out using Lagrange equations of the second kind.

For a mechanical system with one degree of freedom, which is subject to ideal, stationary, holonomic and retaining elms. The Lagrange equation of the second kind has the form:

$$
\frac{d}{d t}\left(\frac{\partial T}{\partial \dot{q}}\right)-\frac{\partial T}{\partial q}=Q
$$

where $q$-generalized coordinate; $\dot{q}$ - generalized speed; $T$ - is the kinetic energy of the mechanical system, expressed in terms of generalized coordinates and velocities; $Q$-generalized force.

To calculate the generalized force $Q$ you need to give the mechanical system a possible displacement $\delta q$, calculate the sum of the active forces on the possible displacements of the points of application of these forces, express all possible displacements of the points of application of forces through the generalized possible displacement $\delta q$, and give the expression for the sum of active forces:

$$
\sum_{k} \delta A_{k}^{a}=Q \cdot \delta q .
$$

The generalized force $Q$ is equal to the coefficient at $\delta q$ in the expression.

4.2. Physico-mathematical model of the mechanical system "automobile wheel-elastic traction compensator"

The mechanical system "automobile wheel-spring compensator of traction force" (Fig. 3) carries out plane parallel movement without separation from a surface and sliding.

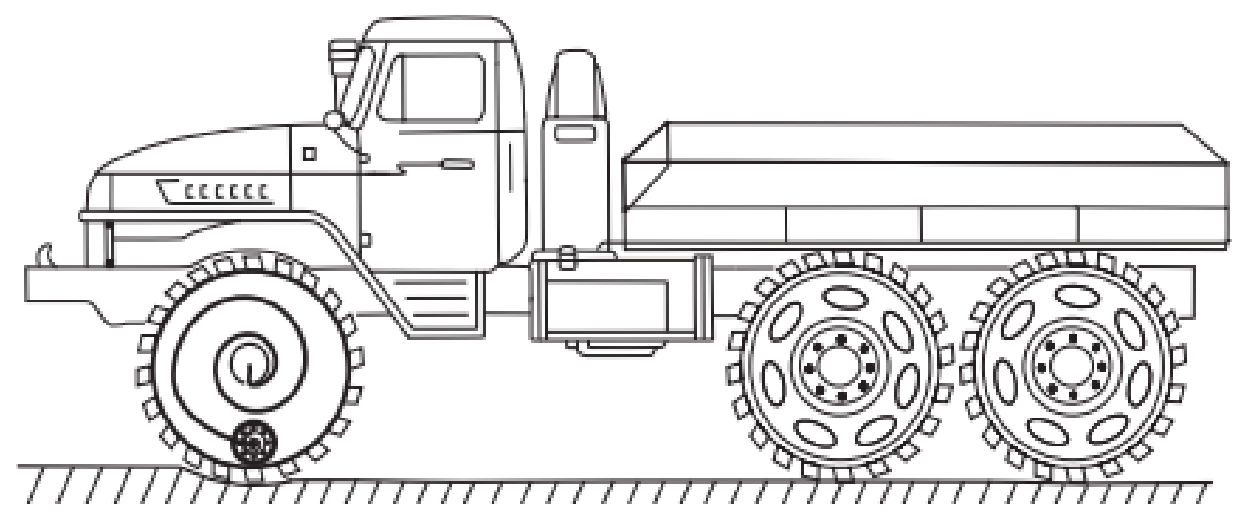

Fig. 3. Mechanical system "automobile wheel-spring compensator of traction force"

This technical system has one degree of freedom.

To describe the mathematical model, consider separately the dynamic model "automotive wheelspring traction compensator", Fig. $4[9,10]$. 


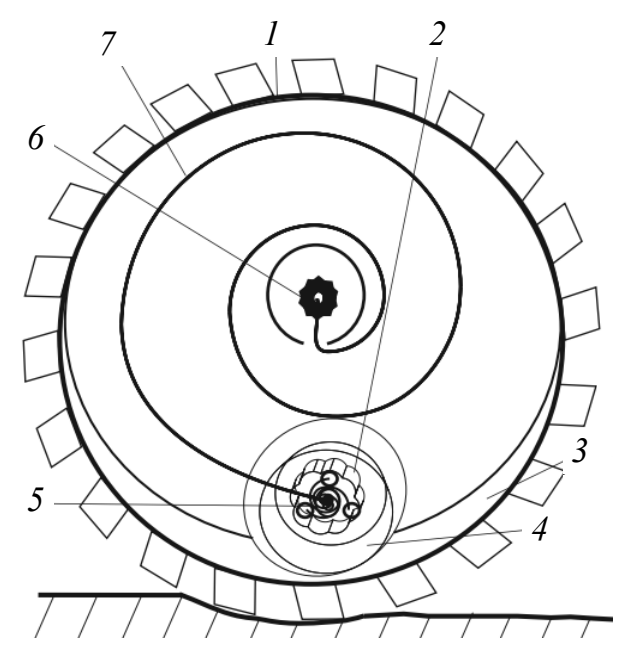

$a$

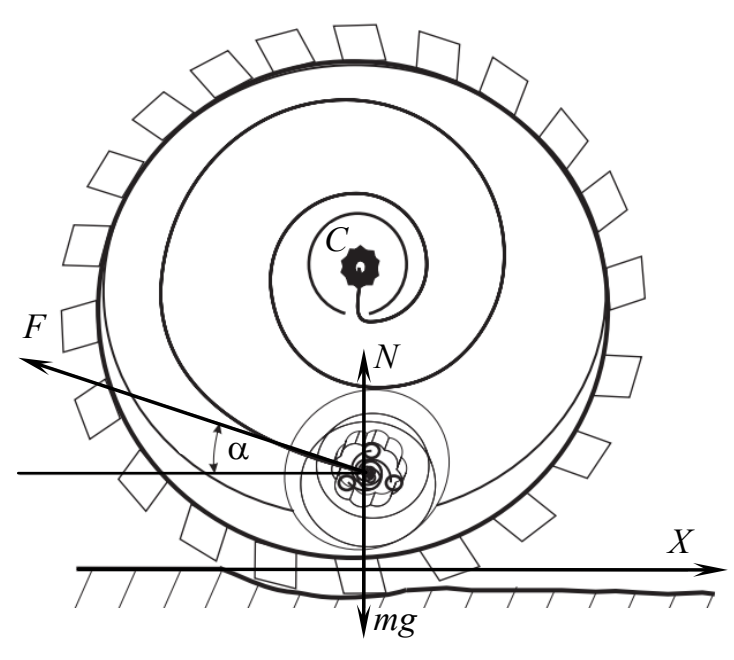

$b$

Fig. 4. Schemes of movement of the system "automobile wheel-spring compensator of traction force": $a$-dynamic model "automotive wheel-spring traction compensator"; $b$ - physical and mathematical model of the mechanical system "automobile wheel-spring compensator of traction force"; 1 - wheel; 2 - wave energy collection; 3 - racetrack; 4 - avalanche; 5 - elastic energy storage; 6 - adjusting screw;

7 - the main elastic drive

The coordinate of the center of the mechanical system "automobile wheel-spring compensator of traction force" will be taken as a generalized coordinate.

On the mechanical system "automobile wheel-spring compensator of traction force" operate:

- active forces: $m g$ - gravity;

$-F$ is the force of the compressed spring.

Communication reactions:

$-N$ - normal component;

$-P$ - friction force (does not work).

Gravity is a potential force, its point of application remains at the same level relative to the horizontal surface. In the first approximation, we believe that its potential inertia:

$$
P=0 \text {. }
$$

The kinetic energy of the mechanical system "automotive wheel-spring traction compensator" will be determined from the formula:

$$
T=T_{1}+T_{2},
$$

where $T_{1}=\frac{1}{2} m\left(\frac{d x}{d t} 2\right)^{2}-$ kinetic energy of translational motion; $T_{1}=\frac{1}{2} I \omega^{2}=\frac{1}{2} R^{2}\left(\frac{d x}{d t}\right)^{2}-$ energy of rotational motion.

In the absence of slippage, the conditions of the speed of the mechanical system and the speed of gradual motion are related by the relation:

$$
\omega R=d x / d t .
$$

Calculate the generalized force that corresponds to the force $F$ applied to the mechanical system - "automotive wheel-spring traction compensator". The elementary work performed by the force $F$ will correspond to the formula:

$$
\delta A=\delta A_{\text {post }}+\delta A_{\text {obert }} .
$$


Work in the translational motion of the mechanical system "automobile wheel-spring compensator of traction force" will correspond to the formula:

$$
\delta A_{\text {post }}=F \cos \alpha \cdot \delta x .
$$

The work in the rotational motion of the mechanical system "automotive wheel-spring traction compensator" will correspond to the equation:

$$
\delta A_{\text {obert }}=M_{z} \delta \varphi .
$$
mula:

The projection of the moment of force created by the moving weight will correspond to the for-

$$
M_{z}=F \cdot r .
$$

In the absence of slippage of the mechanical system "car wheel-spring compensator of traction force" elementary displacement will correspond to the formula:

$$
\delta x=R \delta \varphi .
$$

Then the operation of the mechanical system "car wheel-spring traction compensator" in rotational motion in the final version will look like:

$$
\delta A_{\text {obert }}=F \cdot r \cdot \frac{d x}{R}=F \frac{r}{x} \delta x .
$$

Given that the force $F$ acts at an angle $\alpha$ so the formula for elementary work will look like:

$$
\delta A=F\left(\cos \alpha-\frac{r}{R}\right) d x .
$$

With this distribution of forces, the generalized force will look like:

$$
Q=F\left(\cos \alpha-\frac{r}{R}\right) \text {. }
$$

The Lagrange function can be represented as:

$$
L=T+P=\frac{1}{2}\left(m+\frac{I}{R^{2}}\right)\left(\frac{d x}{d t}\right)^{2} .
$$

The differential equation with respect to the generalized coordinate $x$ will look like:

$$
\left(m+\frac{I}{R^{2}}\right) \frac{d^{2} x}{d t^{2}}=F\left(\cos \alpha \frac{r}{R}\right) .
$$

The path to be traversed by the mechanical system "automotive wheel-spring traction compensator" will be as follows:

$$
x=x_{0}+v_{0} t+\frac{w t^{2}}{2},
$$

where $K$ - the load factor of the running system of the truck, which mathematically has the form:

$$
K=F \frac{\left(\cos \alpha-\frac{r}{R}\right)}{\left(m+\frac{I}{R^{2}}\right)} .
$$

Fig. 5 shows the movement of the truck under the action of force $F$ in the area of the contact spot "car wheel-spring traction compensator" with the support surface. 


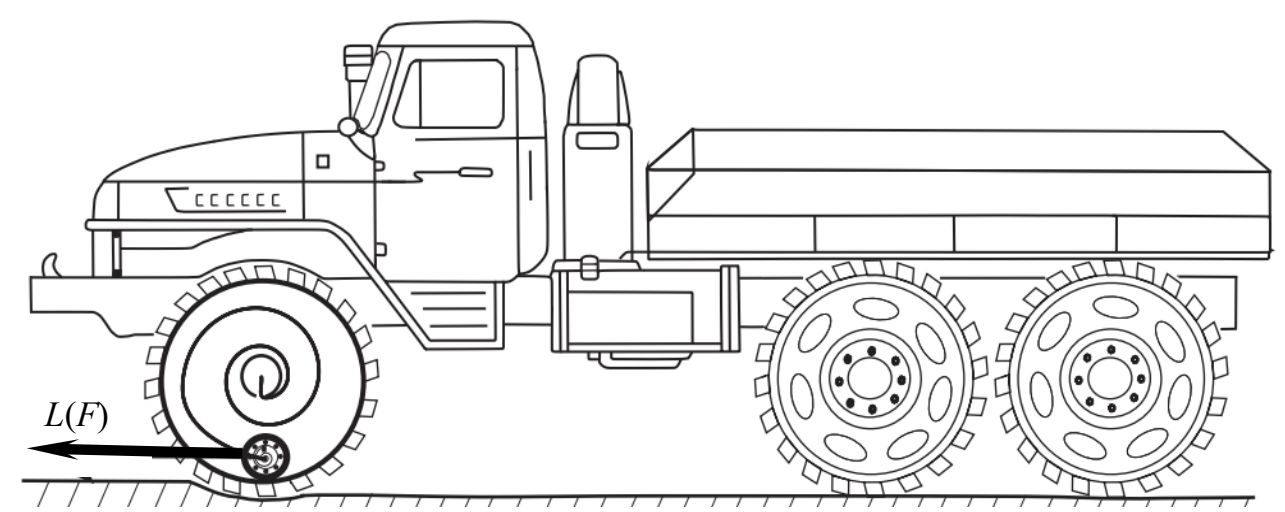

Fig. 5. The movement of the truck under the action of force $F$ in the area of the contact spot "automotive wheel-spring traction compensator" with the support surface

\section{The results of research}

Calculations of theoretical research were performed in Excel.

The results of theoretical research are presented in the graphs, Fig. 6, and in Table 1.

Table 1

Research results

\begin{tabular}{|c|c|c|c|c|c|c|c|}
\hline \multicolumn{2}{|c|}{ Parameters } & \multicolumn{6}{|c|}{ Results } \\
\hline$\alpha$ & $F \quad V$ & 0.1 & 0.2 & 0.3 & 0.4 & 0.5 & 0.6 \\
\hline 00 & 2187.524 & 0.110376 & 0.441505 & 0.993386 & 0.996386 & 0.999386 & 1.00238599 \\
\hline 00 & 2187.524 & 0.110376 & 0.441505 & 0.993386 & 0.996386 & 0.999386 & 1.00238599 \\
\hline 00 & 2187.524 & 0.110376 & 0.441505 & 0.993386 & 0.996386 & 0.999386 & 1.00238599 \\
\hline 00 & 2187.524 & 0.110376 & 0.441505 & 0.993386 & 0.996386 & 0.999386 & 1.00238599 \\
\hline 00 & 2187.524 & 0.110376 & 0.441505 & 0.993386 & 0.996386 & 0.999386 & 1.00238599 \\
\hline 00 & 2187.524 & 0.110376 & 0.441505 & 0.993386 & 0.996386 & 0.999386 & 1.00238599 \\
\hline 00 & 2187.524 & 0.110376 & 0.441505 & 0.993386 & 0.996386 & 0.999386 & 1.00238599 \\
\hline 00 & 2187.524 & 0.110376 & 0.441505 & 0.993386 & 0.996386 & 0.999386 & 1.00238599 \\
\hline 15 & 2068.263 & 0.104413 & 0.417653 & 0.939719 & 0.942719 & 0.9457186 & 0.94871856 \\
\hline 15 & 2068.263 & 0.104413 & 0.417653 & 0.939719 & 0.942719 & 0.9457186 & 0.94871856 \\
\hline 11 & 2123.219 & 0.107161 & 0.428644 & 0.964448 & 0.967448 & 0.9704485 & 0.97344848 \\
\hline 11 & 2123.219 & 0.107161 & 0.428644 & 0.964448 & 0.967448 & 0.9704485 & 0.97344848 \\
\hline 25 & 1859.598 & 0.09398 & 0.37592 & 0.845819 & 0.848819 & 0.8518191 & 0.8548191 \\
\hline 25 & 1859.598 & 0.09398 & 0.37592 & 0.845819 & 0.848819 & 0.8518191 & 0.8548191 \\
\hline 25 & 1859.598 & 0.09398 & 0.37592 & 0.845819 & 0.848819 & 0.8518191 & 0.8548191 \\
\hline 25 & 1859.598 & 0.09398 & 0.37592 & 0.845819 & 0.848819 & 0.8518191 & 0.8548191 \\
\hline 25 & 1859.598 & 0.09398 & 0.37592 & 0.845819 & 0.848819 & 0.8518191 & 0.8548191 \\
\hline 25 & 1859.598 & 0.09398 & 0.37592 & 0.845819 & 0.848819 & 0.8518191 & 0.8548191 \\
\hline 25 & 1859.598 & 0.09398 & 0.37592 & 0.845819 & 0.848819 & 0.8518191 & 0.8548191 \\
\hline 25 & 1859.598 & 0.09398 & 0.37592 & 0.845819 & 0.848819 & 0.8518191 & 0.8548191 \\
\hline \multirow[t]{2}{*}{35} & 1554.55 & 0.078727 & 0.31491 & 0.708547 & 0.711547 & 0.7145473 & 0.71754728 \\
\hline & $t$ & 0.01 & 0.02 & 0.03 & 0.03 & 0.03 & 0.03 \\
\hline
\end{tabular}




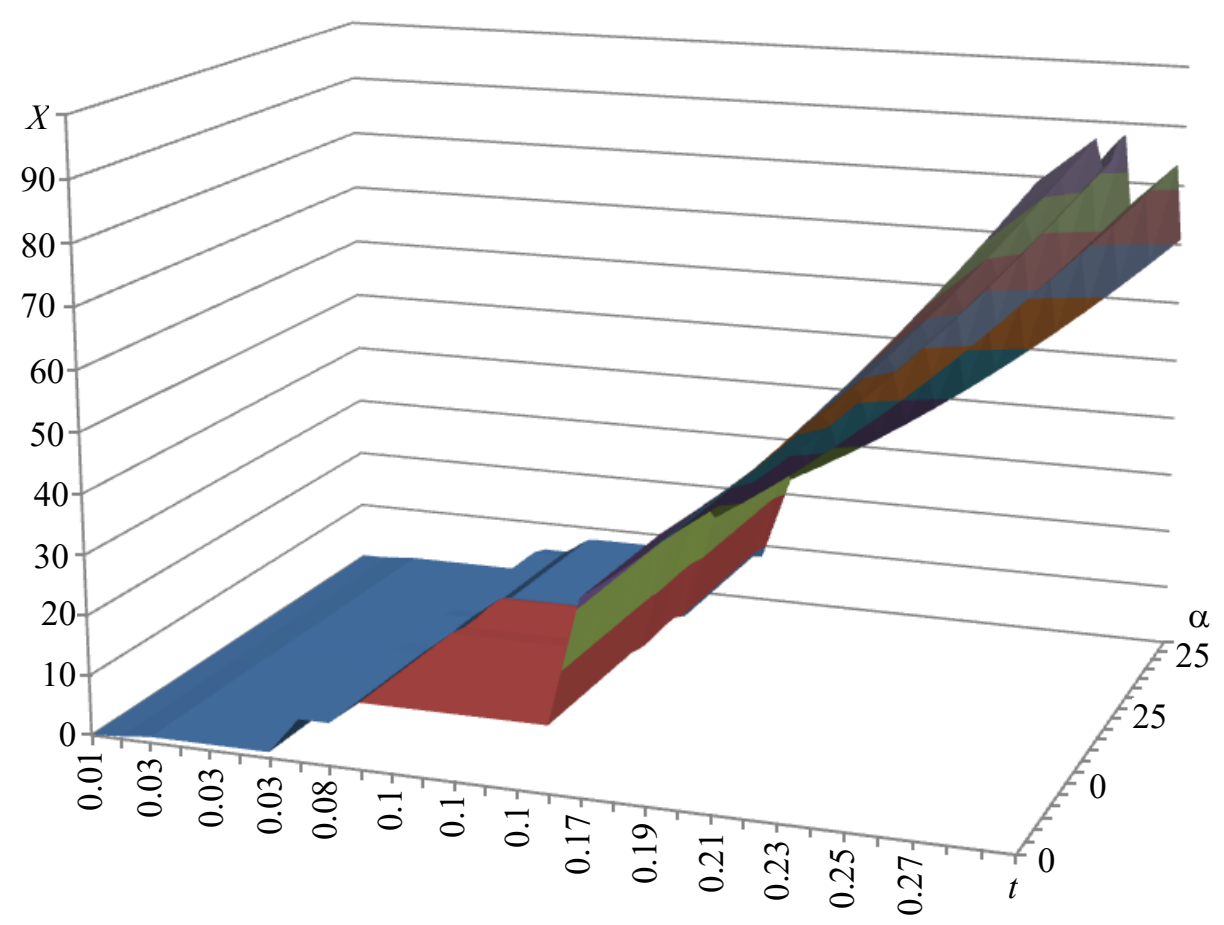

Fig. 6. Influence on the dynamics of truck movement (mechanical system "car wheel-spring traction compensator") time and angle of loading of the treadmill with an elastic energy storag

\section{Conclusions}

The publication examines the dynamics of the automotive system, which is closely related to the interaction of the main energy storage and technological storage and its subsystems, which are used in the operation of the car wheel through their interaction.

The process of moving the truck can be subordinated to the process of rolling the process drive on the treadmill of the wheel drive.

A mathematical model of rolling the wheel drive of a truck using the theorem on the change of kinetic energy of the mechanical system "automobile wheel-spring traction compensator", the general equation of dynamics, as well as the Lagrange equation of the second kind were developed.

The zone of the most effective work of rolling of a wheeled engine by means of rotational movement of elastic elements is revealed.

The possibility of creating a theoretical model of a wheel drive by the interaction of the main energy storage device and the technological drive and its subsystems is revealed.

An alternative source of energy for truck wheels is energy that accumulates in the area of the treadmill, and then, in the interaction of the main energy storage and the technological drive and its subsystems, is used in deformed parts of the tire (as mechanical energy) and is converted into potential energy and vice versa into the kinetic energy of motion of the entire structure of the truck.

\section{Література}

1. Петров Л. М., Скоріченко О. І. Елементи теорії перетворення сліду контакту колісного рушія автомобіля з опорною поверхнею в головний момент сил інерції стиснутої частки шини. С. 126139. DOI: https://doi.org/10.30525/978-9934-588-65-5.8.

2. Янчевский В. Линии жизни протектора. Коммерческий транспорт. 2007. № 2. С. 134-136.

3. Спосіб переміщення автомобільної системи Петрова-Борисенка: пат. 145878 Україна № u202004824; заяв. 28.07.2020; опубл. 06.01.2021, Бюл. № 1. 5 с. 
4. Колесо транспортного засобу: пат. 142331 Україна № u202000063; заяв. 02.01.2020; опубл. 25.05.2020, Бюл. № 10.7 с.

5. Березін Л.М., Кошель С.О., Кошель Г.В. Теоретична механіка. Статика. Київ : Центр учбової літератури, 2013. $122 \mathrm{c}$.

6. Березін Л.М., Кошель С.О., Кошель Г.В. Теоретична механіка. Кінематика. Київ : Центр учбової літератури, 2014. 93 с.

7. Кошель С., Леонід Березін, Ганна Кошель. Теоретична механіка. Київ : Центр навчальної літературиб 2020. $156 \mathrm{c}$.

8. Ловейкін В.С., Ромасевич Ю.О. Аналіз та синтез режимів руху механізмів вантажопідйомних машин: монографія. Київ : Компрінт, 2012. 298 с.

9. Дюндик С.М. Модель для дослідження динаміки підвіски автомобіля спеціального призначення. Збірник наукових прац̧ь Національної академї̈ Національної гвардї Украӥни. 2019. Вип. 1. С. 45-53.

10. Пружне колесо транспортного засобу: пат. 1269 Україна № 2001074968; заяв. 14.07.2001; опубл. 17.06.2002; Бюл. № 8.

\section{References}

1. Petrov, L.M., \& Skorichenko, O.I. Elements of the theory of transformation of a trace of contact of a wheel engine of the car with a basic surface in the main moment of forces of inertia of the compressed share of the tire with, 126-139. DOI: https://doi.org/10.30525/978-9934-588-65-5.8.

2. Yanchevsky, V. (2007). Lines of tread life. Commercial transport, 2, 134-136.

3. Petrov, L.M., \& Borisenko, T.M. (2021). Patent Ukraine № 145878. A method of moving the automotive system Petrov-Borisenko. 06.01.2021; Bull. № 1.

4. Cherneta, O.G., Averyanov, V.S., Sasov, O.O., Kubich, V.I., \& Stasevich, O.R. (2020). Patent Ukraine № 142331. Wheel of the vehicle. 25.05.2020; Bull. № 10 .

5. Berezin, L.M, Koshel, S.O., \& Koshel, G.V. (2013). Theoretical mechanics. Statics. Kyiv: Center for Educational Literature.

6. Berezin, L.M., Koshel, S.O., \& Koshel, G.V. (2014). Theoretical mechanics. Kinematics. Kyiv: Center for Educational Literature.

7. S. Koshel, Leonid Berezin, \& Anna Koshel. (2020). Theoretical mechanics. Kyiv: Center for Educational Literature.

8. Loveykin, V.S., \& Romasevich, Y.O. (2012). Analysis and synthesis of modes of movement of hoisting machines: monograph. Kyiv: Komprint.

9. Dundik, S.M. (2019). Model for studying the dynamics of the suspension of a special purpose vehicle. Collection of scientific works of the National Academy of the National Guard of Ukraine, 1, 45-53.

10. Mostotsky, S.O., \& Bondarev, V.M. (2002). Patent Ukraine № 1269. Elastic wheel of the vehicle, 17.06.2002; Bull. № 8 .

Петров Леонід Миколайович; Petrov Leonid, ORCID: https://orcid.org/0000-0001-5709-9986

Петрик Юрій Миколайович; Petryk Yuriy, ORCID: https://orcid.org/0000-0003-4589-4282

Received March 25, 2021

Accepted May 18, 2021 